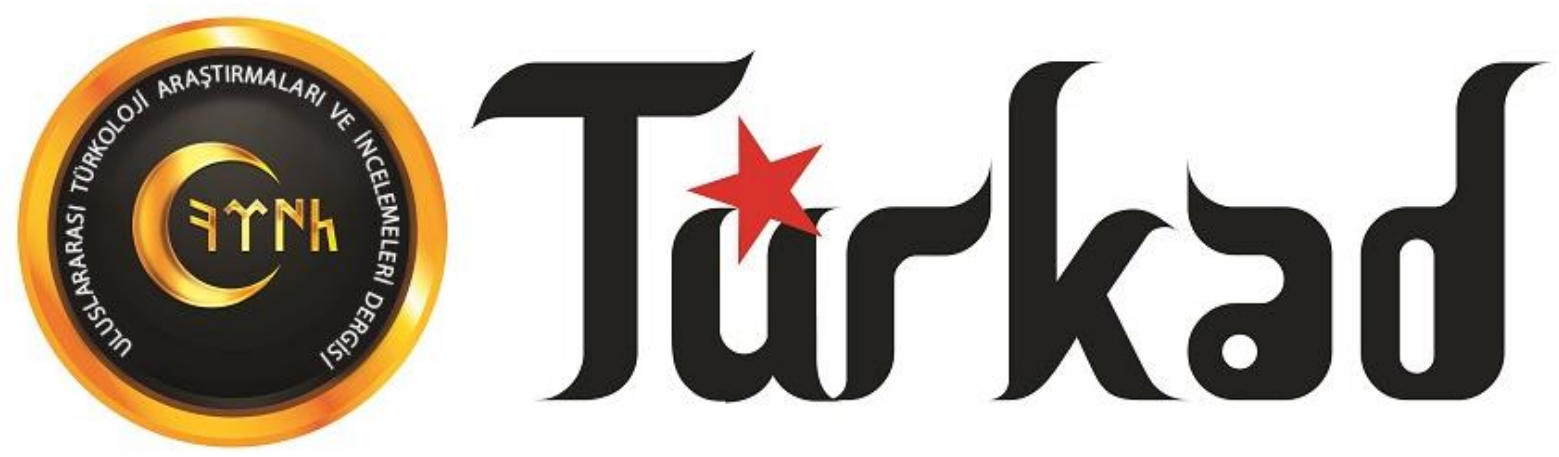

\title{
Yabancı Dil Olarak Türkçe Öğrenen Öğrencilerin Türkiye Türkçesine İlişkin Tutumu: Gazi TÖMER Örneği
}

\author{
Elif YAPRAK ${ }^{1}$ \& Aliye USLU ÜSTTEN² \\ Özet
}

Türkçenin yabancı dil olarak öğretimi, üniversitelerin bünyesinde kurulan TÖMER’lerde, özel kurslar ve çevrimiçi ortamlarda hız kazanmıştır. Bu programlara katılarak Türkçe öğrenmek için gelen öğrencilerin yanında; kalıcı göç etmek, iş bulmak, kariyerine Türkiye'de devam etmek isteyenler de bulunmaktadır. Bu durum, dil öğrenmeye yönelik tutumların üçlü bir yapıya sahip olduğunu göstermektedir. Bilişsel, davranışsal ve duyuşsal olarak adlandırılan bu üçlü sistemde Türkçeyi mesleklerinde uzmanlaşmak veya iş bulmak için öğrenen öğrenciler bilişsel; Türkçeyi Türk kültürüne ve Türk diline karşı olumlu duygularla öğrenen kişilerde duyuşsal, tüm bu nedenlerle veya başka gerekçelerle de olsa amacını belirleyip Türkçe öğrenmeyi eyleme dökenler de davranışsal kapsamda yer almaktadır. Bu çalışmada Gazi Üniversitesi Gazi TÖMER'de yabancı dil olarak Türkçe öğrenen yabancı öğrencilerin Türkçe öğrenmeye karşı tutumlarının çeşitli değişkenler açısından incelenmesi amaçlanmıştır. Açık ve Akcin (2019) tarafından oluşturulan "Türkiye Türkçesi Öğrenmeye İlişkin Tutum Ölçeği”nin kullanıldığı bu çalışmada nicel desenli tarama (survey) uygulanmıştır. A2 seviyesi öğrencilerine uygulanan ölçek SPSS 25.0 kullanılarak analiz edilmiştir. Bağımsız değişkenlerde $t$ testi ve tek yönlü varyans analizi (ANOVA) kullanılmıştır. Araştırma sonucuna göre ögrrencilerin cinsiyet ve yaşa göre Türkçeye olan tutumunda anlamlı farklllık görülmemiştir.

Anahtar sözcükler: Türkçenin yabancı dil olarak öğretimi, dil eğitimi, tutum.

\section{The Attitude of Students Learning Turkish as a Foreign Language towards Turkey Turkish: Example of Gazi TÖMER}

\begin{abstract}
Teaching Turkish as a foreign language, gained speed in TÖMER, which was established in the construction of universities, private courses and environments. Besides attending these programs to learn Turkish; there are also those who want to immigrate permanently, find a job and continue their career in Turkey. This situation shows that attitudes towards language learning have a triple structure. In cognitive, behavioral and affective triad system, students who learn Turkish in order to specialize in their profession or to find a job are cognitively; those who are talented in Turkish and learn Turkish with positive feelings towards the Turkish language affective; those who are because of all these reasons or even if it is another reason, determine their purpose and learn Turkish are behavioral. In this study, it is aimed to examine the attitudes of foreign students who learn Turkish as a foreign language in Gazi University Gazi TÖMER in terms of various variables. In this study, "Attitude Scale Towards Learning Turkey Turkish" which was created by Açık and Akcin (2019), a quantitative pattern survey was applied. The scale applied to A2 level students was analyzed using SPSS 25.0. Independent variables were t-test and one-way analysis of variance (ANOVA). According to the results of the research, there was no significant difference in the attitude of students to Turkish according to gender and age.
\end{abstract}

Key words: Teaching Turkish as a foreign language, language education, attitute.

\footnotetext{
${ }^{1}$ Gazi Üniversitesi, Gazi Eğitim Fakültesi Türkçe Eğitimi Anabilim Dalı Yabancılara Türkçe Öğretimi Programı Yüksek Lisans Öğrencisi, e-posta: elif.yaprak1@gazi.edu.tr 0000-0002-8096-2730

2 Prof. Dr., Gazi Üniversitesi, Gazi Eğitim Fakültesi Türkçe ve Sosyal Bilimler Eğitimi, Türkçe Eğitimi Ana Bilim Dalı, aliyeuslu@gazi.edu.tr 0000-0002-2937-6154
} 


\section{Giriş}

Türkçenin yabancı dil olarak öğretimi, günümüzde ilgi gören ve gelişmekte olan bir sahadır. Neredeyse tüm şehirlerde yer alan Türkçe öğretim merkezlerine zamanla yenisi eklenmekte, bunlara ek olarak özel kurslar açılmakta hatta çevrimiçi ortamda Türkçe öğretme uygulamaları ve Türkçe öğretmeye yönelik siteler bulunmaktadır. Bütün bunlar son yıllarda uygulamaya geçen politik ve kültürel antlaşmalar doğrultusunda hız kazanmıştır. Türk İşbirliği ve Koordinasyon Ajansı (TİKA), Millî Eğitim Bakanlığı, Dışişleri Bakanlığı, Diyanet İşleri Başkanlığı, Yükseköğretim Kurulu (YÖK) ve benzeri birçok kurumun yürütücülüğünde gündeme gelen öğrenci değişimi ve öğrencileri Türkçe öğrenmeye teşvik eden programlar oluşturulmuştur. "Bugün epey uzun bir ifadeyle 'Orta Asya Türk Cumhuriyetleri ve Akraba Topluluklar' olarak anılan profildeki öğrencilerin büyük bir çoğunluğu Türkiye Cumhuriyeti'nin verdiği burslar çerçevesinde Türkçe öğrenmektedirler." (Durmuş ve Okur, 2018: 9). 1992 yllında başlayan Büyük Öğrenci Projesi ile Türkiye'nin kardeş ülke ve topluluklarla ortak değerlerinin yenilenerek kaynaşmasını tesis etmek amaçlanmıştır.

Belli başlı programlara katılarak Türkçe öğrenmek için gelen öğrencilerin yanında; kalıcı göç etmek, iş bulmak, kariyerine Türkiye'de devam etmek isteyenler ve bu amaca hizmet edecek şekilde hedef belirleyen insanlar bulunmaktadır. Garret, Coupland ve Williams (2003: 3) bu durumu, dil öğrenmeye yönelik "tutumların üçlü bir yapı"ya sahip olduğu görüşüyle açıklamaktadırlar. Bilişsel, davranışsal ve duyuşsal olarak adlandırdıkları bu üçlü sistem Türkçe öğrenmek açısından bakıldığında, Türkçeyi mesleklerinde uzmanlaşmak veya iş bulmak için öğrenen öğrenciler bilişsel kapsamda; Türkçeyi Türk kültürüne ve Türk diline karşı olumlu duygularla öğrenen kişilerde duyuşsal kapsamda, son olarak tüm bu nedenlerle veya başka gerekçelerle de olsa amacını belirleyip Türkçe öğrenmeyi eyleme dökenler de davranışsal kapsamda yer almaktadır. Tutum ve tavır geliştirme duyularının etkin, daha ağırlıklı yer aldığı bir süreç olarak tanımlandığında duyuşsal kapsamın Türkçeye karşı tutumdaki etkisi ve önemi de doğru orantılı şekilde anlaşılacaktır.

Bilişsel açıdan öğretim ve ona yönelik hedeflerini yerine getiren bir öğrencinin, bunun yanında duyuşsal anlamda da gelişmesi beklenmektedir. "Özellikle bilişsel hedeflere yönelmiş eğitim öğretim faaliyetlerinin işlevselliğinin, duyuşsal boyuta biraz daha önem verilmesi ile sağlanabileceği ifade edilebilir" (Gömleksiz ve Kan, 2012: 1160-1161).

Günümüzde Türkiye'de eğitim görmek veya daha sonraki eğitimine Türkiye'de devam etmek isteyen birçok yabancı öğrenci bulunmaktadır. Gazi Türkçe Öğretim Merkezi (TÖMER) bu öğretim merkezlerinden biridir. Gazi Üniversitesi Gazi TÖMER'de eğitim gören öğrencilerin Türkçeye olan tutumlarını ölçmenin verilen eğitimde yön belirleyici bir etki sunacağı düşünülmektedir. Türkçenin yabancı dil olarak öğretiminde diğer yabancı dil eğitimlerinde olduğu gibi öğrencilerin dile karşı tutumları araştırma konusu olmaktadır. Bu çalışmada dile yönelik tutum, duyuşsal kapsamda incelenecektir. Araştırmada, Türkçenin bilişsel anlamdaki zorlayıcılığı, yabanc1 öğrencilerin Türkçe öğrenirken Türkçeye verdikleri önem, Türkçe konuşan insanlara karşı duydukları his Türkçenin onlar için yararlı olup olmayacağı, Türk dili yanında Türk kültürüne gösterdikleri ilgiyi ölçmeyi amaçlamaktadır.

\subsection{Tutum Kavram1}

Tutum kavramı Türk Dil Kurumu Sözlüğü'nde tutulan yol veya tavır; Cambridge Sözlük'te ise bir şey veya bir kişi hakkında bir duygu, fikir ya da bunun neden olduğu bir davranış şekli olarak tanımlanmıştır. Genel olarak olumlu tutum veya olumsuz tutum şeklinde ayırt edilebilecek ve hislerin yön verdiği bir olgu olarak tutum, amaçlara göre şekillenir. Smith'e (1971: 82) göre dili sevmek veya sevmemek doğuştan öğrenilen bir şey değildir, öğrenci sınıfa mümkün olduğunca tarafsız bir tutum sergileyerek girerse öğrencinin dil öğrenme tutumu bundan güçlü bir şekilde etkilenecektir. Bu tür bir durumu artı değere 
çevirmek çoğunlukla öğrencinin elindedir. Yeni bir tutum geliştirmek, psikolojik açıdan öğrenmeye karş1 hevesli olmak ve motivasyon sağlamakla mümkündür. Bireyin psikolojisinden beslenen tutum kavramı, aynı zamanda bireyin kültür dünyasından da etkilenmektedir. Sahip olduğu inanç, değerler, bakış açısı, dünya görüşü ve benzeri değişkenlerle şekillenmektedir. Kişiler sahip olduğu bu özellikler ile kendi tutumlarını belirlemekle kalmaz, başkalarına da kendilerine dair fikirler verebilmektedir. Akcin'e (2019: 51) göre "Davranışlara bakarak tutumlara dair fikir yürütebiliriz. Fikir yürütmelerin gerçekçi ve uygun bir şekilde ortaya konabilmesi için, tutum kavramının doğru bir şekilde belirlenmesi ve değerlendirilmesi gerekmektedir. Aksi takdirde yanıltıcı sonuçlara ulaşmak da mümkün olabilir".

\subsection{Dil Tutumu ve İletişimsel İşlevler}

Amaca göre şekillenen tavirlardan oluşan tutumlar, Mathiot ve Garvin'e (1975) göre dil işlevlerini de oluşturmaktadır. "İnsan dili bir amaç, için kullanırken aynı zamanda bir eylem de gerçekleştirir. İletişim sürecinde ortaya çıkan bu eylemler, dil öğretiminde 'dil işlevleri' olarak adlandırılır." (Deniz ve Çekici, 2021: 3). Dil işlevleri (iletişimsel işlevler) sosyalleşmenin etrafında şekillenerek ortaya çıkmaktadır. Kültürün sosyal çevreye yayılarak insanları çevrelemesiyle dil tutumu kavram1, diğer dillere ve sahip olunan dile yönelik duyuşsal bir kapsam alanıyla birlikte algılanmaktadır. Kişilerin tutumunu etkileyen değerler, aynı zamanda ortak sosyal gruplar bularak kaynaşması anlamına da gelmektedir. Bu ortak anlam dünyasının oluşturduğu atmosfere göre öğrencilerin motivasyonları artmakta veya azalmaktadir.

Öğrencilerin Türkçe öğrenme dersine karşı anlamsız / anlamlı, sıkıcı / zevkli, zor / kolay olduğunu düşünme eğilimleri dil öğrenimi sırasında karşılaşılan unsurlardandır. Dil tutumu kavramı ayrıca incelenmiş ve üzerinde çalışmalar yapılmıştır. Baker (1992: 29'dan akt. Garrett, Coupland ve Williams, 2003: 12), dil tutumunu dile dair pek çok alt başlığ kapsayan bir kavram olarak nitelendirmiştir. Bunlar:

- Dil değişkelerine, lehçelerine ve konuşma şekline yönelik tutum

- Yeni bir dil öğrenmeye yönelik tutum

- Bir azınlık diline yönelik tutum

- Dil gruplarına, topluluklarına ve azınlıklarına yönelik tutum

- Dil derslerine yönelik tutum

- Dil derslerine yönelik ebeveyn tutumu

- Dilin özel bir kullanımına yönelik tutum

- Dil seçimine yönelik tutum olarak belirtilmiştir.

Dil tutumunun sosyal, politik ve diğer değişkenleri etrafında genişlediği, birden fazla değişkenle bireyi etkileme durumunun oldukça yüksek olduğu ayrıca görülmektedir. Genel olarak yabancı dil olarak Türkçenin öğretiminde dil tutumunun doğru anlaşılması, eğitim öğretim sürecinin lehine işlemesini sağlayan bir konudur. Dile olan tutum, hedef dilin öğrenicileri ve öğreticileri açısından uygun ortam, program, strateji ve teknikler kullanılarak öğrenme ve öğretmede avantaja dönüştürülebilir.

Araştırmanın problemini Gazi Üniversitesi Gazi TÖMER'de Türkçe öğrenen öğrencilerin Türkçeye ilişkin tutumlarının çeşitli değişkenler (yaş ve cinsiyet) açısından incelenmesi oluşturmaktadır. Araştırmada; Gazi Üniversitesi Gazi TÖMER'de Türkçe öğrenen öğrencilerin Türkçeye ilişkin tutumları yaş ve cinsiyete bağlı olarak incelenmesi ve elde edilen sonuçlar doğrultusunda öğretim sürecinde dil öğrenme motivasyonu sağlama ve öğretim programına yönelik öneriler sunulması amaçlanmaktadır. Araştırmanın önemi, anket sorularına cevap olarak verilen "katılıyorum" ve "kesinlikle katılıyorum" sonuçlarından hareketle, Gazi Üniversitesi TÖMER öğrencilerinin Türkçeye karşı tutumlarını saptayarak 
yabancı öğrencilerin Türkçe öğrenirken Türkçeye verdikleri önem, Türkçe konuşan insanlara karş1 duydukları his Türkçenin onlar için yararlı olup olmayacağı, Türk dili yanında Türk kültürüne gösterdikleri ilgiyi ölçmektir. Alanyazında Gazi Üniversitesi TÖMER öğrencilerinin Türkçeye karşı tutumlarını belirlemeye yönelik yapılan spesifik bir nicel çalışma olmasıyla yer alacaktır.

\section{Yöntem}

$\mathrm{Bu}$ bölümde araştırmanın modeli, çalışma grubu, veri toplama araçları, verilerin toplanması ve analiz hakkında bilgi verilmiştir.

\subsection{Araştırmanın Modeli}

Bu çalışma, Gazi Üniversitesi TÖMER öğrencilerinin Türkiye Türkçesi öğrenimine ilişkin tutumunu ölçmek için yapılmış nicel yönteme dayanan bir araştırmadır. Gerçekliği araştırmacıdan bağımsız gören, kendi dışında olan gerçekliğin de nesnel olarak gözlenip ölçülüp analiz edilebileceğini kabul eden pozitivist görüş nicel araştırmaları tanımlamaktadır (Büyüköztürk, Çakmak, Akgün, Karadeniz, Demirel, 2019: 12). Araştırmanın modeli betimsel tarama modelidir. Bir grubun belirli özelliklerini belirlemek için verilerin toplanmasını amaçlayan çalışmalara tarama-araştırması denir (Büyüköztürk ve diğerleri, 2019: 15).

\section{2. Çalışma Grubu}

2019-2020 eğitim öğretim y1l1, Gazi Üniversitesi TÖMER'de Türkçe öğrenen A2 kur seviyesi öğrencileriyle gönüllülük esasına dayalı ölçek uygulaması yapılmıştır. Çalışma grubu 50 katılımcıdan oluşmaktadır. Toplamda 180 kişinin oluşturduğu evrenden 50 kişilik örneklem alınarak çalışma yapılmıştır. 31 erkek ve 19 kız katılımcı içinde çoğunluğu lisans öğrencisi düzeyinde 18 ve 20 yaş arasında olup 18 yaşın altında 5 kişi bulunmaktadır. 18 yaş altı en az 14 yaş bulundurmakta, 20 yaş üzeri ise en fazla 30 yaşinda katılımcıyı barındırmaktadır. Türkçe öğrenen bu örneklem grubu öğrencileri toplamda 22 farklı ülkeden gelmiştir.

\subsection{Veri Toplama Aracı}

2019-2020 eğitim öğretim y1lı güz döneminde Gazi Üniversitesi Gazi TÖMER'de A2 kur seviyesindeki öğrencilere gönüllülük esasına dayanarak "Türkiye Türkçesi Öğrenmeye İlişkin Tutum Ölçeği" uygulanmıştır. Veri toplama aracı olarak Açık ve Akcin (2019) tarafından oluşturulan "Türkiye Türkçesi Öğrenmeye İlişkin Tutum Ölçeği" kullanılmıştır. Ölçek, likert türü 5 dereceli ve 16 maddeden oluşan bir ölçektir. Çalışma grubuna uygulanan ölçeğin bağımsız $t$ testi ve tek yönlü varyans analizi ile $p$ değerinin 0,01 ila 0,05'e bağlı homojenlik sonuçları elde edilmiş ve buradan hareketle farklılık yorumları yapılmıştır.

\subsection{Verilerin Analizi}

Araştırmadan elde edilen veriler, aşağıda açıklandığı şekilde sayısallaştırılmıştır. Ölçeğe ait maddeler "kesinlikle katılıyorum = 5", "katılıyorum= 4", "kararsızım= 3", "katılmıyorum= 2", "hiç katılmıyorum= 1 puan" olacak şekilde 5'ten 1'e doğru; Kişisel Bilgi Formu'ndaki ifadeler ise seçenek sayısına göre 1 puandan başlanmak üzere 1'er puanlık artış yapılarak kodlanmıştır. Bu veriler, SPSS programında analiz edilmiştir. "Tek yönlü varyans analizi (ANOVA)" ve "bağımsız örneklemler için t-testi" kullanılmıştır. Standart sapma, ortalama, frekans ve yüzde değerleri de hesaplanmıştır. Verilerden elde edilen sonuçlar $\mathrm{p}<.05$ anlamlılık düzeyi dikkate alınarak değerlendirilmiștir. 


\section{Bulgular ve Yorum}

Tablo 1. Bağımsız değişken olarak yaş için frekans ve yüzdeler

\begin{tabular}{lllll}
\hline & Frekans & Yüzde & $\begin{array}{l}\text { Geçerli } \\
\text { Yüzde }\end{array}$ & $\begin{array}{l}\text { Kümülatif } \\
\text { Yüzde }\end{array}$ \\
\hline 18 yaş alt1 & 5 & 10,0 & 10,0 & 10,0 \\
18 yaş & 9 & 18,0 & 18,0 & 28,0 \\
19 yaş & 6 & 12,0 & 12,0 & 40,0 \\
$\begin{array}{l}20 \text { yaş ve } \\
\text { üstü }\end{array}$ & 30 & 60,0 & 60,0 & 100,0 \\
Toplam & 50 & 100,0 & 100,0 & \\
\hline
\end{tabular}

Tablo 1'e göre ise, katılımın büyük kısmı \%60'lık diliminin 20 yaş ve üstü tarafından oluştuğu dikkat çekmektedir. 18 yaş altı katılımcılar ise en küçük dilim olarak \%10'luk kısmı oluşturmuştur.

Tablo 2. Bağımsız değişken olarak cinsiyet için frekans ve yüzdeler

\begin{tabular}{lllll}
\hline & Frekans & Yüzde & $\begin{array}{l}\text { Geçerli } \\
\text { Yüzde }\end{array}$ & $\begin{array}{l}\text { Kümülatif } \\
\text { Yüzde }\end{array}$ \\
\cline { 2 - 5 } Kadın & 19 & 38,0 & 38,0 & 38,0 \\
Erkek & 31 & 62,0 & 62,0 & 100,0 \\
Toplam & 50 & 100,0 & 100,0 & \\
\hline
\end{tabular}

Tablo 2'de görülmekte olan katılımcıların cinsiyete göre sayıları (frekans) ve yüzdeleri ise erkeklerin çoğunlukta olduğuna dikkat çekmektedir.

Araştırmaya katılanlardan elde edilen verilerin bağımsız t testi sonucuna göre öğrencilerin Türkçe öğrenmeye yönelik tutumları ve cinsiyet arasındaki ilişki Tablo 3'te görülmektedir. Tablo 3'te cinsiyet sayıları (N), aritmetik ortalama, standart sapma ve standart hata görülmektedir. 19 kadın 31 erkek olan katılımcıların sağladığı p değeri 0,05’ten büyük çıkarak verinin homojenliğini belirtmiştir. Anovanın ön şartı verilerin homojenlik göstermesi olduğu için tek yönlü varyans analizi Anova uygulanmıştır. Bağımsız gruplar için değişken sayısı iki (kadın ve erkek) olduğu için ise t-testi uygulanmıştır.

Tablo 3. Katılımcıların Türkçe ögrenmeye yönelik tutumları ile ilgili toplam puanlarının cinsiyet değişkenine göre t-testi sonuçlar

\begin{tabular}{lllllll}
\hline Cinsiyet & N & Ort. & SS & Sd & T değeri & P \\
\hline Kadın & 19 & 56,1579 & 9,30510 & \multirow{2}{*}{, 38} & \multirow{2}{*}{692} \\
Erkek & 31 & 55,0645 & 9,50065 & & & \\
\hline
\end{tabular}

Tablo 3’teki analiz sonuçlarına göre, katılımcıların Türkçe öğrenmeye yönelik tutumları ile toplam puanları cinsiyet değişkenine göre anlamlı bir farklılık göstermemektedir $\left[\mathrm{t}_{(48)}=, 398 ; \mathrm{p}>, 05\right]$. Kadınların Türkçe öğrenmeye yönelik tutum davranışları ile ilgili toplam puanlarının aritmetik ortalaması Ort=56,15 iken erkeklerin Türkçe öğrenmeye yönelik tutum davranışları ile ilgili toplam puanlarının aritmetik ortalaması $(\mathrm{Ort}=55.06)$ dır. Aradaki sayısal fark istatistiksel açıdan anlamlı bir farklılık oluşturmamaktadır. Bu bulgu katılımcıların Türkçe öğrenmeye yönelik tutum görüşleri ile cinsiyetleri arasında anlamlı bir ilişki olmadığı şeklinde yorumlanabilir. 
Tablo 4. Katılımcıların Türkçe öğrenmeye yönelik tutumlar ile ilgili toplam puanlarının yaş değişkenine göre farklılığ için tek yönlü varyans analizi (anova) sonuçları

\begin{tabular}{|c|c|c|c|c|c|c|c|}
\hline Değişken & & & & $\mathbf{N}$ & Ort. & & $\mathbf{S}$ \\
\hline \multirow{8}{*}{ Yaş } & 18 yaş alt1 & & & 5 & 50,20 & & 7,25948 \\
\hline & 18 yaş & & & 9 & 53,22 & & 10,18305 \\
\hline & 19 yaş & & & 6 & 57,50 & & 9,18150 \\
\hline & 20 yaş ve ü & & & 30 & 56,63 & & 9,41196 \\
\hline & $\begin{array}{l}\text { Varyansın } \\
\text { Kaynağı }\end{array}$ & $\mathbf{K T}$ & Sd & KO & $\mathbf{F}$ & $\mathbf{P}$ & $\begin{array}{l}\text { Fark } \\
\text { Scheffe }\end{array}$ \\
\hline & $\begin{array}{l}\text { Gruplar } \\
\text { Aras1 }\end{array}$ & 249,658 & 3 & 83,219 & ,950 & 424 & \multirow{3}{*}{-} \\
\hline & Gruplar İçi & 4030,822 & 46 & 87,627 & & & \\
\hline & Toplam & 4280,480 & \multicolumn{2}{|l|}{49} & & & \\
\hline
\end{tabular}

Tutum bağımlı değişkeni üzerinde yapılan bir başka test ise diğer bağımsız değişken olan yaş değişkeninin düzeyini ölçmektir. Değişkene bağlı değerler sayısı 4'e ayrılmaktadır. 18 yaş altı, 18 yaş, 19 yaş, 20 yass ve üstü. Betimleyici tabloda dağılımlarının aralığının fazla olması dikkat çekmektedir. Aralıklar arası fark artışını düzenlemek için post-hoc analizler de yapılmış fakat $\mathrm{p}$ değerinin 0,05 değerini aşması değişiklik göstermemiştir. Anova testi için ön şartlardan biri olan homojenliğin sağlandığı görülmektedir. (Tablo 3 sig değeri) Bu test sonuçlarından varılan istatistik yorum ise Türkçe diline ve öğrenimine ilişkin tutumun yaşa göre anlamlı bir biçimde farklılaşmadığıdır. Tablo 4’te görülen sig (p) değerinin $(, 424) 0,05$ ’ten oldukça büyük olması bu yoruma etken olan veri olarak görülmektedir.

Tablo 4'teki analiz sonuçlarına göre, katılımcıların Türkçe öğrenmeye yönelik tutumları ile ilgili toplam puanları ile yaş değişkeni arasında anlamlı bir farklılık gözlenmemiştir. $\left[\mathrm{F}_{(3-46)}=, 950 ; \mathrm{p}>, 05\right]$. Dolayıs1 ile ayrıyeten bir post-hoc testi olan Scheffe yapılmasına gerek yoktur. Scheffe boş birakılmıştır.

Tablo 5. Yaş ve cinsiyet değişkenleri için standart sapma ve ortalama

\begin{tabular}{llll}
\hline $\mathrm{N}$ & Geçerli & Yaş & Cinsiyet \\
\cline { 3 - 4 } & Kayıp & 50 & 50 \\
Ortalama & & 0 & 0 \\
$\begin{array}{l}\text { Standart } \\
\text { (std.) }\end{array}$ & Sapma & 3,2200 & 1,6200 \\
\hline
\end{tabular}

Tablo 5'te yaşa göre verilen kodlamada; 18 yaş altı 1'e, 18 yaş 2'ye, 19 yaş 3'e, 20 yaş ve üstü ise 4'e kodlayarak yapılmış ve buna yönelik olarak yaş ortalamasının 3,22 verisinden hareketle 19 olarak belirlendiği ve katılımcıların yaşlarının ortalama 19 olarak göründüğü saptanmiştır.

Tablo 6. Katılımcıların ana dili tutum puanlarına ilişkin dağılımı

\begin{tabular}{|c|c|c|c|c|c|c|c|c|c|c|}
\hline \multirow[b]{3}{*}{$\begin{array}{l}\text { Türkçe } \\
\text { dünyadaki en } \\
\text { önemli } \\
\text { dillerden } \\
\text { biridir. }\end{array}$} & \multicolumn{2}{|c|}{$\begin{array}{l}\text { Kesinlikle } \\
\text { katılmiyorum }\end{array}$} & \multicolumn{2}{|c|}{ Kat1lmiyorum } & \multicolumn{2}{|c|}{ Karars1z1m } & \multicolumn{2}{|c|}{ Kat1liyorum } & \multicolumn{2}{|c|}{$\begin{array}{l}\text { Kesinlikle } \\
\text { kat1livorum }\end{array}$} \\
\hline & $\mathrm{N}$ & $\%$ & $\mathrm{~N}$ & $\%$ & $\mathrm{~N}$ & $\%$ & $\mathrm{~N}$ & $\%$ & $\mathrm{~N}$ & $\%$ \\
\hline & 4 & $\% 8$ & 13 & $26 \%$ & 14 & $28 \%$ & 11 & $22 \%$ & 8 & $16 \%$ \\
\hline
\end{tabular}




\begin{tabular}{|c|c|c|c|c|c|c|c|c|c|c|}
\hline $\begin{array}{l}\text { Türkçenin } \\
\text { seçmeli ders } \\
\text { olarak } \\
\text { okutulmasını } \\
\text { isterim. }\end{array}$ & 3 & $6 \%$ & 9 & $18 \%$ & 11 & $22 \%$ & 20 & $40 \%$ & 7 & $14 \%$ \\
\hline $\begin{array}{l}\text { Ülkemizde } \\
\text { Türkçe devlet } \\
\text { politikası } \\
\text { olsun isterim. }\end{array}$ & 10 & $20 \%$ & 10 & $20 \%$ & 14 & $28 \%$ & 10 & $20 \%$ & 6 & $12 \%$ \\
\hline $\begin{array}{l}\text { Türkçe } \\
\text { konuşan } \\
\text { insanlarla } \\
\text { iletişim } \\
\text { kurmak } \\
\text { isterim. }\end{array}$ & 1 & $2 \%$ & 1 & $2 \%$ & 9 & $18 \%$ & 13 & $26 \%$ & 26 & $52 \%$ \\
\hline $\begin{array}{l}\text { Türkçenin de } \\
\text { ülkemizde } \\
\text { kullanılan } \\
\text { yabancı diller } \\
\text { arasında } \\
\text { öncelikli } \\
\text { olmasını } \\
\text { isterim. }\end{array}$ & 3 & $6 \%$ & 11 & $22 \%$ & 14 & $28 \%$ & 13 & $26 \%$ & 9 & $18 \%$ \\
\hline $\begin{array}{l}\text { Türkçe müzik } \\
\text { dinlemeyi } \\
\text { severim. }\end{array}$ & 5 & $10 \%$ & 6 & $12 \%$ & 6 & $12 \%$ & 16 & $32 \%$ & 17 & $34 \%$ \\
\hline $\begin{array}{l}\text { Türkçe ile } \\
\text { yayın yapan } \\
\text { TV programı, } \\
\text { film, dizi gibi } \\
\text { yapımları } \\
\text { takip ederim. }\end{array}$ & 3 & $6 \%$ & 8 & $16 \%$ & 10 & $20 \%$ & 17 & $34 \%$ & 12 & $24 \%$ \\
\hline $\begin{array}{l}\text { Türkçe } \\
\text { öğrenmek iş } \\
\text { kariyerim için } \\
\text { yararlıdır. }\end{array}$ & 3 & $6 \%$ & 3 & $6 \%$ & 11 & $22 \%$ & 17 & $34 \%$ & 16 & $32 \%$ \\
\hline $\begin{array}{l}\text { Türkçe } \\
\text { öğrenmenin } \\
\text { benim için } \\
\text { yararlı } \\
\text { olacağını } \\
\text { düşünüyorum. }\end{array}$ & 1 & $2 \%$ & 5 & $10 \%$ & 6 & $12 \%$ & 17 & $34 \%$ & 21 & $42 \%$ \\
\hline $\begin{array}{l}\text { Ülkemizde } \\
\text { ilkokuldan } \\
\text { itibaren } \\
\text { Türkçe } \\
\text { öğretilmesini } \\
\text { isterim. }\end{array}$ & 10 & $20 \%$ & 15 & $30 \%$ & 8 & $16 \%$ & 9 & $18 \%$ & 7 & $14 \%$ \\
\hline $\begin{array}{l}\text { Türkçenin } \\
\text { konuşulduğu } \\
\text { kültüre karşı } \\
\text { ilgim var. }\end{array}$ & 1 & $2 \%$ & 2 & $4 \%$ & 13 & $26 \%$ & 21 & $42 \%$ & 13 & $26 \%$ \\
\hline $\begin{array}{l}\text { Türkçenin } \\
\text { konuşulduğu } \\
\text { ülkeye karşı } \\
\text { ilgim var. }\end{array}$ & 1 & $2 \%$ & 10 & $20 \%$ & 21 & $42 \%$ & 12 & $24 \%$ & 6 & $12 \%$ \\
\hline $\begin{array}{l}\text { Türkçe } \\
\text { öğrenmenin }\end{array}$ & 7 & $14 \%$ & 13 & $26 \%$ & 10 & $20 \%$ & 13 & $26 \%$ & 7 & $14 \%$ \\
\hline
\end{tabular}




\begin{tabular}{|c|c|c|c|c|c|c|c|c|c|c|}
\hline $\begin{array}{l}\text { zor olduğunu } \\
\text { düşünürüm. }\end{array}$ & & & & & & & & & & \\
\hline $\begin{array}{l}\text { Türkçenin } \\
\text { kulağa hoş } \\
\text { gelen bir dil } \\
\text { olduğunu } \\
\text { düşünüyorum. }\end{array}$ & 3 & $6 \%$ & 3 & $6 \%$ & 18 & $36 \%$ & 13 & $26 \%$ & 13 & $26 \%$ \\
\hline $\begin{array}{l}\text { Türkçe } \\
\text { öğretimi } \\
\text { materyallerini } \\
\text { ilgi duyarım. }\end{array}$ & 1 & $2 \%$ & 8 & $16 \%$ & 14 & $28 \%$ & 17 & $34 \%$ & 10 & $20 \%$ \\
\hline $\begin{array}{l}\text { Türkçe } \\
\text { konuşmanın } \\
\text { zor olduğunu } \\
\text { düşünürüm. }\end{array}$ & 11 & $22 \%$ & 10 & $20 \%$ & 8 & $16 \%$ & 10 & $20 \%$ & 11 & $22 \%$ \\
\hline
\end{tabular}

Anket sonuçlarına göre her maddenin her derecesinin de yüzdesi alınmıştır. "Türkçe dünyadaki en önemli dildir" maddesi için kesinlikle katılıyorum \%16, "Türkçenin seçmeli ders olarak okutulmasını isterim" maddesi için \%14,"ülkemizde Türkçe öğretilmesi devlet politikası olsun" maddesi için \% 12, "Türkçe konuşan insanlarla iletişim kurmak isterim" maddesi için \%52, "Türkçenin ülkemizde kullanılan yabancı diller arasında öncelikli olmasını isterim" maddesi için \%18, "Türkçe müzik dinlemeyi severim" maddesi için \%34, "Türkçe ile ilgili yayın yapan TV programı film dizi gibi yapımları takip ederim" maddesi için \%24, "Türkçe öğrenmek iş kariyerim için yararlıdır" maddesi için \%32, "Türkçe öğrenmenin benim için yararlı olacağını düşünüyorum" maddesi için \%42, "ülkemizde ilkokuldan itibaren Türkçe öğretilmesini isterim" \%14, "Türkçenin konuşulduğu kültüre karşı ilgim var" maddesi için \%26, "Türkçenin konuşulduğu ülkeye karşı ilgim var" maddesi için \%12, "Türkçenin kulağa hoş gelen bir dil olduğunu düşünürüm" maddesi için \%26, "Türkçe öğretim materyallerine ilgi duyarım" maddesi için \%20, "Türkçe konuşmanın zor olduğunu düşünüyorum" maddesi için ise \%22 olarak görülmektedir.

\section{Sonuç ve Öneriler}

Türkiye Türkçesine ve bu dili öğrenmeye karşı farkındalığın arttığı son günlerde dili öğrenmenin nedenleri kadar dili öğrenmeye ilişkin unsurlar da önem arz etmektedir. Bu önemli unsurlardan bir tanesi de tutumdur. "Türkiye Türkçesi Öğrenmeye İlişkin Tutum Ölçeği” 2019-2020 eğitim öğretim y1lı A2 seviyesi Gazi TÖMER öğrencilerine uygulandığında, varyansların homojenliği saptanmış bu nedenle yaş ve cinsiyete göre anlamlı farklılık görülmediği tespit edilmiştir.

Yüzdelerin toplam kişi sayısına (50) göre olumlu tutum, anketin katılıyorum ve kesinlikle katılıyorum dağılımında çeşitlilik görülmektedir. Anketin maddelerinin kesinlikle katılıyorum ve katılıyorum yüzdeleri incelendiğinde; öğrencilerin Türkçeye karşı bildirdikleri olumlu tutumu "Türkçe konuşmanın zor olduğunu düşünüyorum." maddesi için \%22+\%20 ile Türkçe konuşmakta zorlayıc1lı̆ıı az olduğu görülmüştür. Bir konuya verilen önemin kişiler için işlevsel ve faydalı olmasıyla doğru orantılı olduğu düşünüldüğünde, "Türkçe öğrenmek iş kariyerim için yararlıdır." maddesi için \%32+\%34, "Türkçe öğrenmenin benim için yararlı olacağını düşünüyorum." maddesi için \%42+\%34 kesinlikle katılıyorum ve katlıyorum verisi, Türkçeye verdikleri önemin azımsanmayacak nitelikte olduğunu göstermektedir. Ayrıca tutumun duyuşsal kapsamda yer alması ile Türk kültürüne ve Türkiye'ye karşı geliştirilen olumlu hisler Türkçeye karşı tutumu etkilemektedir. Anket ifadeleri arasında yer alan "Türkçenin konuşulduğu ülkeye karşı ilgim var." maddesinde $\% 12+24$ verisinin kesinlikle katılıyorum ve katılıyorum oranı düşük görülmektedir. Bu sebeple kültürün ve ülkenin izlenimini güçlendirmek açısından yapılacak etkinlikler faydalı olacaktır. 
Öğrencilere dilin sevdirilmesine yönelik çalışmalar yapılması da gerekmektedir. Smith'e (1971) göre yüksek motivasyonlu ve başarılı bir kimse farklı düşünen kimsedir. Bu kimse farklı fikirlerle gelen, yaratıcı, kendisine düşünme şansı verilmesini seven bir kimse olacaktır ve dil öğretiminin ilk zamanlarında dahi böyle bir düşünme güçlendirilebilir. Karatay ve Kartallığlu'nun (2016) çalışmasında Türkçeye yönelik tutumun dil becerilerine olan olumlu ve olumsuz etkileri araştırılmış, okuma ve dinleme becerisi ile olumlu ve anlamlı bir ilişkinin varlı̆̆1 saptanmıştır. Temizyürek ve Sallabaş'a (2020) göre Türk soylulara Türkçe öğretiminde verim elde etmek için bu maksatla yazılan kitapların biçim ve içerik yönünden niteliği üzerinde durulması gerekmektedir.

Alan yazından hareketle öğrencilerin tutumlarının değişmesi için düşünce şeklinin güçlendirilmesi, Türkçeye karş1 tutumun öğrencide okuma ve dinlemede etkili olacağının ögrrencilere doğrudan bilgilendirmek yoluyla motivasyon artırımı, bunları yaparken kullanılan materyallerin niteliğine dikkat edilmesi önerilmektedir. Ayrıca yabancı dil olarak Türkçe öğreten öğretim görevlisi veya öğretmenlerin programa göre uygun bir zaman belirleyerek tutum ölçme işlemini gerçekleştirmesi de önerilmektedir. Böylece öğrencilerin ankete verdiği olumlu cevapların yüzdelerinden yola çıkılarak da dersin gidişatına yönelik fikirler geliştirilmelidir. Bütün bunlar eğitim-öğretim sürecini kontrol altına alan faydalı girişimler olacaktır.

\section{Kaynakça}

Adıgüzel, A. (2012). Okula ilişkin tutum ölçeğinin geçerlik ve güvenirlik çalışması. Elektronik Sosyal Bilimler Dergisi, 11: 30-45.

Akcin, H. ve Açık F. (2018). Türk cumhuriyetlerinde ana diline ilişkin dil tutum ölçeğinin geliştirilmesi. Çukurova Üniversitesi Türkoloji Araştırmaları Dergisi, 2(3): 281-301.

Akcin, H. (2019). Türk Cumhuriyetlerinde ana diline ve Türkiye Türkçesi öğrenimine ilişkin tutum. (Üniversite öğrencileri örneğinde). Yayımlanmış Doktora Tezi, Gazi Üniversitesi Eğitim Bilimleri Enstitüsü.

Baker, C. (1992). Attitudes and language. Clevedon: Multilingual Matters.

Büyüköztürk, Ş., Çakmak, E., Akgün, Ö., Karadeniz, Ş. ve Demirel, F., (2019). Eğitimde bilimsel araştırma yöntemleri. Ankara: Pegem Akademi.

Deniz, K. ve Çekici, E. (2021). Türkçenin yabancı dil olarak öğretimine yönelik dil işlevleri. Journal of World of Turks, 13(1), 2021: 1-26.

Durmuş, M. ve Okur, A. (Edt). (2018). Yabancılara Türkçe öğretimi el kitabı. Ankara: Grafiker Yayınları.

Garrett, P., Coupland, N. ve Williams, A. (2003). Investigating language attitudes: Social meanings of dialect, ethnicity and performance. University of Wales Press.

Gömleksiz, N. ve Kan, Ü. (2012). Eğitimde duyuşsal boyut ve duyuşsal öğrenme. Turkish Studies - International Periodical For The Languages, Literature and History of Turkish or Turkic. 7(1), 1159-1177.

Karatay H. ve Kartallığlu N. (2016). Yabancı dil olarak Türkçe öğrenme tutumu ile dil becerileri edimi arasındaki ilişki. AIBÜ Sosyal Bilimler Enstitüsü Dergisi, 16(4), 203213.

Kazazoğlu, S. (2013). Türkçe ve İngilizce derslerine yönelik tutumun akademik başarıya etkisi. Eğitim ve Bilim Dergisi, 38(170), 294-307.

K1lıç, V. (2002). Dilin işlevleri ve iletişim. İstanbul: Papatya Yayıncılık. 
Mathiot, M. ve Garvin, P. (1975). The functions of language: A sociocultural view. Anthropological Quartherly, 48(3), 148-156.

Smith, A. (1971). The importance of attitude in foreign language learning. The Modern Language Journal, 55, 82-88.

Temizyürek, F. ve Sallabaş, M. (2020). Türk dünyasından gelen öğrencilerin Türkiye Türkçesi metinlerine yönelik tutumları. Bilig, (95), 1-26. 